\title{
A new syndrome of congenital hypoparathyroidism, severe growth failure, and dysmorphic features
}

\author{
S A Sanjad, N A Sakati, Y K Abu-Osba, R Kaddoura, R D G Milner
}

\begin{abstract}
Twelve infants (six boys, six girls) with severe hypocalcaemic tetany or convulsions were seen over a three year period. Nine patients were symptomatic in the newborn period. Their hypocalcaemia was associated with hyperphosphataemia and very low concentrations of immunoreactive parathyroid hormone. None of the babies suffered from congenital cardiac disease. Cell mediated immunity, measured in five patients, was normal. There were no chromosomal abnormalities but all patients shared several dysmorphic features including deep set eyes, microcephaly, thin lips, beaked nose tip, external ear anomalies, micrognathia, and depressed nasal bridge. Mental retardation of varying degree was found in all patients. All had severe intrauterine and postnatal growth retardation. Four patients have died. The remaining eight patients are on treatment with vitamin $D$ and calcium supplements with no change in their growth pattern. We believe that this association of congenital hypoparathyroidism with severe growth failure and dysmorphism represents a new syndrome.
\end{abstract}

Hypoparathyroidism represents a range of clinical and biochemical syndromes characterised by parathyroid hormone deficiency, hypocalcaemia, and hyperphosphataemia. Neonatal hypoparathyroidism is relatively common, occurring usually as a transient condition associated with well defined risk factors such as prematurity, perinatal asphyxia, and maternal diabetes. ${ }^{1}$ Permanent congenital hypoparathyroidism is rare. Most cases are caused by defective embryogenesis of structures deriving from the third and fourth pharyngeal pouches and fourth branchial arch-namely the parathyroid glands, thymus, heart and aortic arch, and several facial structures. This constellation of findings is known as third-fourth pharyngeal pouch syndrome or DiGeorge's syndrome. ${ }^{2}$

In the past three years we have identified 12 patients with an unusual syndrome of congenital hypoparathyroidism associated with severe growth failure and dysmorphic features quite distinctive from those of DiGeorge's syndrome. The description of their clinical findings and laboratory investigations is the subject of this report which was presented in part at the 58th Annual Meeting of the Society for Pediatric Research, Washington DC, May 1988. ${ }^{3}$

Patients and methods RECOGNITION OF THE SYNDROME
The index case (case 1) was a 3 year old Saudi boy who was the product of a normal full term pregnancy and spontaneous vaginal delivery. His birth weight was $1500 \mathrm{~g}$. Hypocalcaemic tetany was diagnosed in the first few days of life and was treated with oral calcium supplement and a vitamin D preparation. His parents were first degree cousins and had two older children in perfect health.

He was referred to our care at the age of 4.5 months because of repeated attacks of vomiting and convulsions. His weight was $2.5 \mathrm{~kg}$ and length $47 \mathrm{~cm}$. Physical examination disclosed moderate dehydration and several dysmorphic features including microcephaly, micrognathia, thin lips, low set and posteriorly rotated ears, deep set eyes, depressed nasal bridge and beaked nose tip, and high arched palate. Examination of the heart and lungs showed no abnormalities and there was no abdominal visceromegaly. He had small hands and feet, micropenis, and unilateral cryptorchidism. He had normal blood urea nitrogen and creatinine concentrations and moderate hyponatraemia, which was corrected with appropriate treatment. His serum calcium concentration ranged from 1.5 to $1.7 \mathrm{mmol} / \mathrm{l}$, and inorganic phosphate from $2 \cdot 3$ to $4.0 \mathrm{mmol} / \mathrm{l}$. Parathyroid hormone, measured on five occasions, ranged between $10-30 \mathrm{pmol} / 1$ (normal $29-85 \mathrm{pmol} / \mathrm{l}$ ) despite severe concomitant hypocalcaemia.

Two unrelated patients (cases 2 and 3) with similar phenotypic abnormalities had been seen by one of the authors (NAS) in the preceding 12 months. Both were found to have congenital hypoparathyroidism and severe growth failure. In the next two years, nine additional patients from eight unrelated families fulfilled the criteria for inclusion in this report.

\section{LABORATORY METHODS}

All patients had serial determinations of serum calcium, phosphate, magnesium, albumin, and creatinine concentrations in addition to routine laboratory studies. Parathyroid hormone was measured by radioimmunoassay against the mid region of the molecule utilising a commercial kit (INCSTAR Corporation). T and B lymphocyte quantitation, performed in five patients, was measured by monoclonal antibody with laser beam sorter. T lymphocyte function was measured by blastogenesis with several mitogens including pokeweed, phytohaemagglutinin, and concanavalin A.

Results

CLINICAL AND LABORATORY FINDINGS

Table 1 summarises the clinical and laboratory data of the 12 patients. Sex distribution was
Correspondence to: Dr Sanjad.

Accepted 29 June 1990 
Table 1 Clinical findings in patients with congenital hypoparathyroidism

\begin{tabular}{|c|c|c|c|c|c|c|c|c|c|c|}
\hline \multirow{2}{*}{$\begin{array}{l}\text { Case } \\
\text { No }\end{array}$} & \multirow[t]{2}{*}{ Sex } & \multirow{2}{*}{$\begin{array}{l}\text { Gestational } \\
\text { age (weeks) }\end{array}$} & \multirow{2}{*}{$\begin{array}{l}\text { Birth } \\
\text { weight }(g)\end{array}$} & \multicolumn{2}{|l|}{ Age } & \multirow[t]{2}{*}{ Consanguinity } & \multirow{2}{*}{$\begin{array}{l}\text { Family } \\
\text { history }\end{array}$} & \multirow[t]{2}{*}{ Karyotype } & \multirow{2}{*}{$\begin{array}{l}\text { Mental } \\
\text { retardation }\end{array}$} & \multirow[t]{2}{*}{ Additional data } \\
\hline & & & & $\begin{array}{l}\text { Onset of } \\
\text { symptoms }\end{array}$ & Diagnosis & & & & & \\
\hline 1 & $\mathbf{M}$ & Full term & 1500 & 7 days & 4 months & First cousins & Negative & $46 X Y$ & Moderate & $\begin{array}{l}\text { Recurrent vomiting, pyloric } \\
\text { stenosis, operated }\end{array}$ \\
\hline 2 & $\mathbf{F}$ & Full term & 3000 & 25 days & 25 days & First cousins & Positive & $46 \mathrm{XX}$ & Severe & $\begin{array}{l}\text { Esotropia, nystagmus, accessory } \\
\text { auricle }\end{array}$ \\
\hline 3 & $\mathbf{M}$ & Full term & 1610 & 30 days & 30 days & First cousins & Negative & $46 X Y$ & Moderate & $\begin{array}{l}\text { Death from fulminant pneumonia at } \\
5 \text { months of age }\end{array}$ \\
\hline 4 & $\mathbf{F}$ & Full term & $\begin{array}{l}\text { Low birth } \\
\text { weight }\end{array}$ & 3 months & 3 months & First cousins & Negative & $46 X X$ & Severe & Esotropia \\
\hline $\begin{array}{l}5 \\
6 \\
7\end{array}$ & $\begin{array}{l}\mathbf{M} \\
\mathbf{F} \\
\mathbf{F}\end{array}$ & $\begin{array}{l}35 \\
\text { Full term } \\
34\end{array}$ & $\begin{array}{l}1650 \\
2100 \\
1400\end{array}$ & $\begin{aligned} & 1 \text { day } \\
& 17 \text { days } \\
& 4 \text { months }\end{aligned}$ & $\begin{array}{l}1 \text { day } \\
25 \text { days } \\
4 \text { months }\end{array}$ & $\begin{array}{l}\text { First cousins } \\
\text { First cousins } \\
\text { First cousins }\end{array}$ & $\begin{array}{l}\text { Negative } \\
\text { Positive } \\
\text { Positive }\end{array}$ & $\begin{array}{l}\text { 46XY } \\
\text { ND } \\
\text { ND }\end{array}$ & $\begin{array}{l}\text { Moderate } \\
\text { Moderate } \\
\text { Severe }\end{array}$ & $\begin{array}{l}\text { Died at } 7 \text { months of age, pneumonia } \\
\text { Died at } 2 \text { years of age, sibling of } \\
\text { case } 8\end{array}$ \\
\hline $\begin{array}{l}8 \\
9\end{array}$ & $\begin{array}{l}\mathbf{M} \\
\mathbf{M}\end{array}$ & $\begin{array}{l}\text { Full term } \\
32\end{array}$ & $\begin{array}{l}2150 \\
2100\end{array}$ & $\begin{array}{l}2 \text { days } \\
21 \text { days }\end{array}$ & $\begin{array}{l}12 \text { days } \\
7 \text { months }\end{array}$ & $\begin{array}{l}\text { First cousins } \\
\text { Fourth cousins }\end{array}$ & $\begin{array}{l}\text { Positive } \\
\text { Positive }\end{array}$ & $\begin{array}{l}\text { ND } \\
46 X Y\end{array}$ & $\begin{array}{l}\text { Severe } \\
\text { Severe }\end{array}$ & $\begin{array}{l}\text { Sibling of case } 7 \\
\text { Bilateral corneal opacity, distal renal } \\
\text { tubular acidosis, died at } 9 \text { months } \\
\text { of age }\end{array}$ \\
\hline $\begin{array}{l}10 \\
11 \\
12\end{array}$ & $\begin{array}{l}\mathbf{F} \\
\mathbf{F} \\
\mathbf{M}\end{array}$ & $\begin{array}{l}30 \\
36 \\
\text { Full term }\end{array}$ & $\begin{array}{l}1600 \\
1750 \\
2000\end{array}$ & $\begin{array}{l}2 \text { months } \\
7 \text { months } \\
15 \text { days }\end{array}$ & $\begin{array}{l}15 \text { months } \\
9 \text { months } \\
2 \text { months }\end{array}$ & $\begin{array}{l}\text { First cousins } \\
\text { None } \\
\text { First cousins }\end{array}$ & $\begin{array}{l}\text { Negative } \\
\text { Negative } \\
\text { Negative }\end{array}$ & $\begin{array}{l}46 X X \\
\text { ND } \\
46 X Y\end{array}$ & $\begin{array}{l}\text { Moderate } \\
\text { Mild } \\
\text { Mild }\end{array}$ & Chickenpox at 10 days of age \\
\hline
\end{tabular}

ND, not done.

equal. All but one patient (case 2) suffered from severe intrauterine growth retardation with birth weights ranging from 1500 to $2150 \mathrm{~g}$. Five patients were born prematurely. Ten patients were born of parents who were first degree cousins. Four families had more than one child affected with a similar condition.

The presenting complaint in all patients was hypocalcaemic tetany or generalised convulsions, usually detected in the first few days or weeks of life. In two patients the onset of symptoms was delayed until the fourth and seventh month. Additional manifestations shared by all patients were severe growth failure and psychomotor retardation. Feeding disorders, vomiting, and diarrhoea were other common problems encountered.

The results of the biochemical investigations are listed in table 2 . All patients had moderate to severe hypocalcaemia and hyperphosphataemia. The normal serum calcium found in case 11 was the result of treatment with vitamin $\mathrm{D}$ before her referral to our care. Three patients had a low serum magnesium concentration. The parathyroid hormone concentration was low in all patients despite concomitant severe hypocalcaemia. In cases 6 to 12 parathyroid hormone was reported as less than $30 \mathrm{pmol} / 1$ because this was the limit of detection of the assay. Renal function, judged from serum urea and creatinine concentrations, was normal in all patients.
One patient had an associated distal renal tubular acidosis requiring alkali treatment.

All patients had several dysmorphic features; these and other findings are summarised in table 3. The most characteristic were the craniofacial findings consisting of microcephaly, deep set eyes, thin lips, micrognathia, depressed nasal bridge with beaking of the nose

Table 3 Dysmorphic features and other clinical findings in 12 patients with congenital hypoparathyroidism and severe growth failure

\begin{tabular}{lc}
\hline Abnormal: & \\
Microcephaly & 12 \\
Deep set eyes & 12 \\
Thin lips & 12 \\
Beaked nose tip & 10 \\
Low set and/or posteriorly rotated ears & 10 \\
Micrognathia & 10 \\
Prominent forehead & 10 \\
Depressed nasal bridge & 10 \\
Small hands and feet & 10 \\
Microphthalmos & 6 \\
Esotropia & 5 \\
Micropenis & $4 / 6$ \\
Cryptorchidism & $2 / 6$ \\
Nystagmus & 3 \\
Epicanthic folds & 2 \\
& \\
Normal: & $12 / 12$ \\
Cardiovascular system & $12 / 12$ \\
Absence of visceromegaly & $8 / 8$ \\
Growth hormone & $7 / 7$ \\
Thyroid function & $5 / 5$ \\
Tymphocytes & $5 / 5$ \\
Immunoglobulins & \\
\hline
\end{tabular}

Table 2 Results of biochemical analysis of serum in patients with congenital hypoparathyroidism

\begin{tabular}{|c|c|c|c|c|c|c|c|}
\hline $\begin{array}{l}\text { Case } \\
\text { No }\end{array}$ & $\begin{array}{l}\text { Calcium } \\
(\text { mmoll/l) }\end{array}$ & $\begin{array}{l}\text { Phosphate } \\
\text { (mmolll) }\end{array}$ & $\begin{array}{l}\text { Magnesium } \\
\text { (mmolll) }\end{array}$ & $\begin{array}{l}\text { Alkaline } \\
\text { phosphatase } \\
\text { (IUIl) }\end{array}$ & $\begin{array}{l}\text { Parathyroid } \\
\text { hormone } \\
\text { (pmolll) }\end{array}$ & $\begin{array}{l}\text { Albumin } \\
(\mathrm{g} / \mathrm{l})\end{array}$ & $\begin{array}{l}\text { Creatinine } \\
(\mu \text { moll })\end{array}$ \\
\hline $\begin{array}{c}1 \\
2 \\
3 \\
4 \\
5 \\
6 \\
7 \\
8 \\
9 \\
10 \\
11 \\
12 \\
\text { Normal }\end{array}$ & $\begin{array}{l}1.4 \\
1.6 \\
1.5 \\
1.2 \\
1.3 \\
1.8 \\
1.75 \\
1.67 \\
1.35 \\
1.8 \\
2.29 \\
1.3\end{array}$ & $\begin{array}{l}2.7 \\
3.4 \\
3.3 \\
3.3 \\
4.1 \\
4 \cdot 7 \\
3.2 \\
3.5 \\
3.2 \\
2.44 \\
2.45 \\
3.2\end{array}$ & $\begin{array}{l}1.1 \\
0.8 \\
0.8 \\
1.2 \\
0.8 \\
0.8 \\
0.8 \\
0.55 \\
0.6 \\
0.8 \\
0.8 \\
0.5\end{array}$ & $\begin{array}{r}188 \\
238 \\
88 \\
228 \\
28 \\
118 \\
18 \\
300 \\
216 \\
174 \\
260 \\
150\end{array}$ & $\begin{array}{l}25 \\
20 \cdot 5 \\
19 \\
17 \\
9 \cdot 1 \\
<30 \\
<30 \\
<30 \\
<30 \\
<30 \\
<30 \\
<30\end{array}$ & $\begin{array}{l}38 \\
37 \\
38 \\
35 \\
40 \\
42 \\
44 \\
41 \\
39 \\
42 \\
42 \\
40\end{array}$ & $\begin{array}{l}27 \\
37 \\
28 \\
27 \\
44 \\
40 \\
50 \\
44 \\
60 \\
46 \\
34 \\
35\end{array}$ \\
\hline $\begin{array}{l}\text { Nomilual } \\
\text { val }\end{array}$ & $2 \cdot 1-2 \cdot 6$ & $1 \cdot 2-1 \cdot 95$ & $0 \cdot 75-1 \cdot 0$ & $100-300$ & $30-85$ & $37-47$ & $30-60$ \\
\hline
\end{tabular}



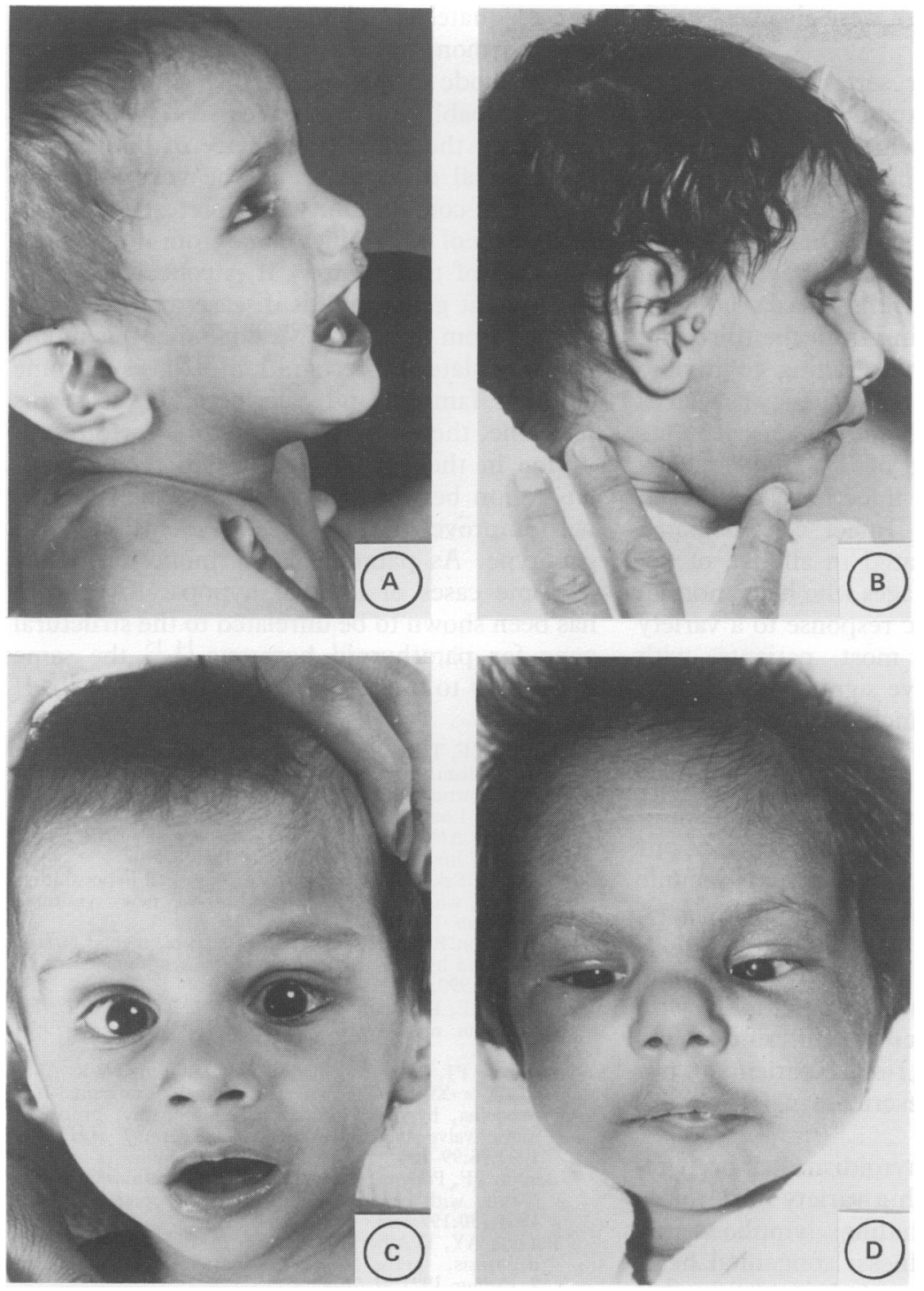

(A) Case 4: girl with deep set eyes, micrognathia, thin lips, and simple malformed posteriorly rotated ears. (B) Case 2: girl with prominent forehead, depressed nasal bridge, deep set eyes, micrognathia, thin lips, and preauricular tags. (C) Case 1: boy with deep set eyes, broad nasal bridge, prominent forehead, and micrognathia. (D) Case 5: boy with deep set eyes, epicanthic folds, broad nasal bridge.
Table 4 Follow up growth data in patients with congenital hypoparathyroidism

\begin{tabular}{|c|c|c|c|c|c|c|}
\hline $\begin{array}{l}\text { Case } \\
\text { No }\end{array}$ & $\begin{array}{l}\text { Birth } \\
\text { weight } \\
\text { (g) }\end{array}$ & $\begin{array}{l}\text { Age } \\
\text { (years) }\end{array}$ & $\begin{array}{l}\text { Weight } \\
(\mathrm{kg})\end{array}$ & $\begin{array}{l}\text { Height } \\
(\mathrm{cm})\end{array}$ & $\begin{array}{l}\text { Weight } \\
\text { (SD score })\end{array}$ & $\begin{array}{l}\text { Height } \\
(S D \text { score })\end{array}$ \\
\hline $\begin{array}{l}1 \\
2 \\
4\end{array}$ & $\begin{array}{l}1500 \\
3000 \\
\text { Low birth }\end{array}$ & $\begin{array}{l}3 \cdot 5 \\
5 \cdot 5\end{array}$ & $\begin{array}{l}5 \cdot 4 \\
6 \cdot 4\end{array}$ & $\begin{array}{l}69 \cdot 0 \\
76 \cdot 0\end{array}$ & $\begin{array}{l}-5 \cdot 8 \\
-5 \cdot 2\end{array}$ & $\begin{array}{l}-7 \cdot 1 \\
-7 \cdot 2\end{array}$ \\
\hline $\begin{array}{l}5 \\
7 \\
8\end{array}$ & $\begin{array}{l}\text { weight } \\
2100 \\
1400 \\
2150\end{array}$ & $\begin{array}{l}3.8 \\
1.3 \\
2.0 \\
1.0\end{array}$ & $\begin{array}{l}7 \cdot 5 \\
4 \cdot 8 \\
2 \cdot 0 \\
4 \cdot 0\end{array}$ & $\begin{array}{l}75 \cdot 0 \\
59 \cdot 0 \\
44 \cdot 5 \\
52 \cdot 5\end{array}$ & $\begin{array}{l}-5 \cdot 4 \\
-5 \cdot 5 \\
-7 \cdot 6 \\
-5 \cdot 3\end{array}$ & $\begin{array}{l}-5 \cdot 9 \\
-7 \cdot 6 \\
-12 \cdot 5 \\
-9 \cdot 0\end{array}$ \\
\hline
\end{tabular}

form of $1,25(\mathrm{OH})_{2} \mathrm{D} 3$ (calcitriol). Dosage ranged from 0.25 to $2.0 \mu \mathrm{g}$ daily by mouth and was titrated against the serum calcium concentration. Several patients have developed hypercalcaemia which reverted to normal soon after reduction or withdrawal of calcitriol. In addition, they all received calcium supplements $(50$ $100 \mathrm{mg} / \mathrm{kg} /$ day of elemental calcium). Two patients required oral magnesium supplements on a temporary basis. Aluminum hydroxide gel was used as phosphate binder in three patients with very high serum phosphate concentrations.

Severe growth failure and psychomotor delay has persisted in all patients despite normalisation of their biochemical abnormalities (table 4). Four patients have died during the course of this study: two from intercurrent infection (pneumonia), the other two from unknown causes.

\section{Discussion}

We consider that these 12 patients represent a new syndrome because of the association of severe prenatal and postnatal growth retardation, similar dysmorphic features, and the early clinical presentation caused by hypoparathyroidism, which was diagnosed on the basis of hypocalcaemia, hyperphosphataemia, and low serum concentrations of immunoreactive parathyroid hormone. Further support for this view is found in the report of a group of patients from Kuwait with the same characteristics. ${ }^{4}$

The most striking abnormalities shared by all our patients were the severe intrauterine (11/12) and postnatal growth retardation. Thus all patients have remained appeciably below the third centile for weight and height despite correction of their biochemical abnormalities with vitamin D treatment. Forced nasogastric feeding, tried in three patients, and parenteral nutrition in one, failed to promote any significant growth. This pronounced growth retardation may be appreciated by examining table 4 , which shows the weight and height SD score of six long term survivors with this syndrome. In general height or length is more severely affected than weight. Case 2, the oldest in the series, weighed only $6.4 \mathrm{~kg}$ and measured $76 \mathrm{~cm}$ at 5.5 years of age.

All patients presented with several dysmorphic findings (table 3). The craniofacial features impart such a characteristic appearance on these patients (figure) that some were diagnosed at first sight by house officers who had seen examples before. Microcephaly, deep set eyes, and thin lips were present in all patients. Beaking of nose tip, micrognathia, prominent forehead, 
and depressed nasal bridge were also very common abnormalities.

Several patients in the series were referred from other hospitals to exclude the diagnosis of DiGeorge's syndrome, which is also characterised by congenital hypoparathyroidism and facial dysmorphism. There are several differences between patients with DiGeorge's syndrome and those we have described. First, in DiGeorge's syndrome there is aplasia or hypoplasia of structures deriving from the third and fourth pharyngeal pouches leading to thymic aplasia and cellular immunodeficiency as well as hypoparathyroidism. ${ }^{25}$ None of our patients showed clinical evidence of $T$ cell deficiency such as chronic monilial infections, diarrhoea, rhinitis, or skin rashes. Intact cell mediated immunity was demonstrated in all five of the patients tested at various ages who had a normal T lymphocyte blastogenic response to a variety of mitogens. Second, most patients with DiGeorge's syndrome have significant congenital cardiac anomalies including conotruncal defects and aortic arch malformations. ${ }^{5}$ Cardiovascular abnormalities were not seen in any of our cases. Third, the facial dysmorphism of DiGeorge's syndrome is quite unlike that of our patients. Commonly described features include hypertelorism, abnormal and pointed ears, anteverted nostrils, micrognathia, and antimongoloid slant. Of these, only micrognathia and possible ear anomalies were comparable with our cases. Lastly, the severe intrauterine growth retardation observed in 11 of 12 patients in our series is not a feature described in DiGeorge's syndrome. $^{2}$

Congenital hypoparathyroidism has been reported in association with a variety of developmental anomalies, including lymphoedema, nephropathy, nerve deafness, congenital heart disease, ${ }^{5-8}$ and chromosomal abnormalities. ${ }^{9-11}$ Some of the reported cases may represent incomplete forms or variants of the third to fourth pharyngeal pouch syndrome of DiGeorge. More recently, congenital hypoparathyroidism has been reported in association with the Silver-Russell syndrome ${ }^{12}$ and the Kenny syndrome of dwarfism, internal cortical thickening, and medullary stenosis of tubular bones. ${ }^{13}$

The pathophysiology of hypoparathyroidism in our patients and its association with the multiple abnormalities described remain elusive to us. With the available data, it is impossible to tell whether the parathyroid glands were absent or hypoplastic or whether they were present but not adequately producing or releasing parathyroid hormone into the circulation.

The mode of inheritance in this syndrome is most probably autosomal recessive. This is suggested by the equal occurrence in both sexes, the familial incidence, and the very high frequency of consanguinity. Of interest is the fact that seven of 12 families came from the western province of the country. It is conceivable that the mutant gene for this disease may have originated from that area. We hope that this report will stimulate the recognition of the syndrome in other families and elsewhere. If, as seems probable, there is a high gene dose for the syndrome in the Kingdom of Saudi Arabia, collaboration between the paediatricians involved will improve the chance of identifying the genotype. As parathyroid hormone deficiency in some cases of familial hypoparathyroidism has been shown to be unrelated to the structural gene for parathyroid hormone, ${ }^{14} 15$ the same may apply to the syndrome we have described.

1 Mimouni F, Tsang RC. Disorders of calcium and magnesium metabolism. In: Neonatal perinatal medicine. In: Fanaroff AA, Martin RJ, eds. Diseases of the fetus and infant. 4th Ed. St Louis: CV Mosby, 1987:1077-93.

2 DiGeorge AM. Discussion on a new concept of the cellular base of immunology. 7 Pediatr 1965;67:907.

3 Sanjad S, Sakati N, Abu-Osba Y. Congenital hypoparathyroidism with dysmorphic features-a new syndrome. I Pediat 1988;23:271A.

4 Richardson RJ, Kirk JMW. Short stature, mental retardation, and hypoparathyroidism: a new syndrome. Arch Dis tion, and hypoparathyr.

5 Conley ME, Beckwith JB, Mancer JFK, Tenckhoff $L$. The spectrum of DiGeorge syndrome. $\mathcal{F}$ Pediatr 1979;94: 883-90.

6 Dahlberg PJ, Borer WZ, Newcomer KL, Yutuc WR. Autosomal or X-linked recessive syndrome of congenital lymphedema, hypoparathyroidism, nephropathy, prolapsing mitral valve and brachytelephalangy. Am $\mathcal{F}$ Med Gene 1983;16:99-104.

7 Benson PF, Parsons V. Hereditary hypoparathyroidism presenting with oedema in the neonatal period. $Q \mathcal{F} \mathrm{Med}$ 1964;130:197-208.

8 Barakat AY, D'Albora JB, Martin MM, Jose PA. Familia nephrosis, nerve deafness and hypoparathyroidism. f Pediatr 1977;91:61-4.

9 Koenig R, Kessel E, Schoenberger W. Partial monosomy 10p syndrome. Ann Genet 1985;28:173.

10 Gencik A, Bronniman V, Tober R, Auf der Maur P. Partial monosomy of chromosome 10 short arms. $\mathcal{F}$ Med Genet 1983;20:107-11.

11 Kelley RI, Zackai EH, Emmanuel BS, Kistanmacher M Greenberg F, Punnett HH. The association of the Greenberg F, Punnett HH. The association of the DiGeorge anomalad with partial

12 Hansen KK, Latson LA, Buehler BA. Silver-Russell syndrome with unusual findings. Pediatrics 1987;79:125-8.

13 Fanconi S, Fischer JA, Wieland P, et al. Kenny syndrome: evidence for idiopathic hypoparathyroidism in two patients and for abnormal parathyroid hormone in one. $\mathcal{F}$ Pediat 1986;109:469-75.

14 Ahn TG, Antonarakis SE, Kronenberg HM, Igarashi T, Levine MA. Familial isolated hypoparathyroidism: a molecular genetic analysis of 8 families with 23 affected persons. Medicine 1986;65:73-81.

15 Schmitdke J, Kruse K, Pape B, Sippell G. Exclusion of close linkage between the parathyroid hormone gene and a mutant gene locus causing idiopathic hypoparathyroidism. $\mathcal{f}$ Med Genet 1986;23:217-9. 